\title{
POTENTIAL IMPACT OF COMMODITISATION ON ROOF TOP SOLAR PV IN INDIA
}

\author{
Kausar Suraiya Quraishi* \\ Research Scholar, Department of Business Administration, \\ Aligarh Muslim University, Aligarh, India \\ Dr. Salma Ahmed PhD, \\ Professor, Department of Business Administration, \\ Aligarh Muslim University, Aligarh, India \\ *Corresponding Author
}

\begin{abstract}
The present study attempts to understand the concept of commoditisation and its potential impact on Roof Top Solar (RTS) PV in India. Solar PV is a growing industry and it is beginning to play a major role in the electricity mix in our country. The objective of this study is to understand the need for India to commoditise PV for effective implementation, bringing about a paradigm shift in harnessing energy from the abundant freely available sunshine. Commoditization can be a prerequisite for enhanced and speedier adoption of PV even in homes. The study is based on the secondary data collected from Research articles, renewable energy journals and websites of solar energy organisations. The study helps understand the elements and the factors responsible for commoditisation which can culminate in aggressive market development of RTS. Assessing India's stance to bring about rapid commoditisation and how best to tackle the problems encountered in the Indian scenario are elucidated. The basic idea of the researcher is to lay emphasis on producing a roof top model that can be plugged in a socket to produce your own energy. The study concludes that potential challenges like effective net metering implementation, grid connectivity, fragmented electricity market, thrust for green financing etc. have to be addressed to trigger the growth of RTS.
\end{abstract}

Keywords: Commoditisation, Grid, Photo voltaic (PV), Residential Solar Roof Tops (RTS) Regulatory policies, tax incentives

Cite this Article: Kausar Suraiya Quraishi and Dr. Salma Ahmed, Potential Impact of Commoditisation on Roof Top Solar PV in India, International Journal of Management, 10 (5), 2019, pp. 48-60.

http://iaeme.com/Home/issue/IJM?Volume $=10 \&$ Issue $=5$ 


\section{INTRODUCTION}

\subsection{Concept of RTS}

RTS requires only input sunlight, requires no water to produce electricity, generates no carbon dioxide or other heat trapping gases that contribute to climate change, produces none of the harmful emissions or wastes. PV is impacted by insolation values like time of the year, latitude, weather conditions, roof slope, roof aspect, shade from adjacent buildings and vegetation. India being a tropical country, the sun shines almost 300 days in most parts of the year as in some of the Indian states like Rajasthan, Gujarat, Madhya Pradesh, Telangana, Odisha, Andhra Pradesh, Karnataka, Kerala and Tamil Nadu, where RTS can be effectively adopted.

\subsection{Environmental Impact of RTS}

The latest global Environmental Performance Index rankings released on23rd January 2018 on the side-lines of World Economic Forum meet in Davos, Switzerland, saw India slip to $177^{\text {th }}$ position from $141^{\text {st }}$ including air quality and carbon dioxide emission intensity per unit of GDP. India cannot waste the limited fossil fuels and foreign exchange on their imports. The Government is committed to reduce carbon emissions by $30-35 \%$ by 2030 and to increase the share of renewables to $40 \%$ of the energy mix by 2040 . So RSTPV can be adopted by India in view of the environmental advantages:

- Clean and visually unobtrusive in nature and with no polluting emissions like greenhouse gases.

- Uses little or no water in the production of zero emission electricity.

- Can be placed in virtually most geographical regions in India owing to the availability of sunshine.

- No overhead wires-no transmission losses.

- Has a predictable energy curve and is most efficient when utility rates are at their highest.

- Can be permitted and installed faster than any other traditional or renewable power plant.

\subsection{Economic Impact of RTS}

The Indian Solar market is dominated by the Commercial and Industrial Roof Top segments, contrary to the global trend. This is primarily due to high DISCOM tariffs for the Industrial and Commercial categories in the country. As of March 2017, the total roof top solar capacity in the country stood at $1.3 \mathrm{GW}$ of which about $42 \%$ or $590 \mathrm{MW}$ was in the Industrial consumer segment, $22.4 \%$ or $313 \mathrm{MW}$ in the Commercial segment and only $21.7 \%$ or $303 \mathrm{MW}$ in the Residential Solar Roof Top segment while the remaining was installed on Government buildings. The Solar Energy Corporation of India (SECI) is the implementing agency for MNRE's Roof Top subsidy programme where 30\% capital subsidy is provided in the general category States/Union territories and 70\% in special category States including North Eastern states, Sikkim, Can Uttarakhand, Himachal Pradesh, Jammu \& Kashmir, Lakshadweep and Andaman and Nicobar Islands. More than $80 \mathrm{MW}$ worth of projects were commissioned under the subsidy scheme. The economic advantages of RTS are as follows:

- Can be permitted and installed faster than any other traditional or renewable power plant mitigating against future electricity

- Produces local, on-site energy, peaking power supply which reduces tail end voltages and also reduces the need for extensive high voltage transmission lines or complex infrastructure, reducing transmission and distribution losses.

- Reliable over the long term. With no moving parts, fixed PV systems which last longer than other energy systems.

- Creates avenues for low cost financing with use of third-party ownership for cost reduction.

- Creates good local jobs for the new energy economy. 


\subsection{Measuring Potentiality of Commoditisation}
i. Technical potential: resource potential
ii. Economic potential: paying capacity of a household.
iii. Market potential: Market dynamics, demand-supply dynamics and acceptability.

\subsection{Commoditisation of RTS}

Today, RTS is seen is a viable option and its use can be economic, safe, clean, pollution free, more so having an aesthetic appeal. To increase public acceptance of this technology commoditisation of Residential Solar Roof Tops can be the right technological solution. Conrad Burke -Marketing Director of Dupont PV Solutions maintains that RTS is not a commodity, the reason deduced being the current selling price and the actual cost of producing the panels-i.e. the profit and loss can never be correctly arrived at. RTS product can be considered as a commodity when it has a predictable and uniform quality and can be bought and sold. It should become indistinguishable and sold on the basis of price and not brand, inviting more suppliers to lower the price. Furthermore, competitors need to enter the market to make quick profits. The price of RTS should be determined by market demand. Technological development of PV can lead to commoditisation. Further RTS can become commoditised when the product is standardised, and usable and the price is enough to justify creating a market for it. The market should move from a differentiated market to an undifferentiated price competition, from monopolistic competition to perfect competition. The financial definition of commoditisation is to homogenise a product. Commoditisation of RTS can occur when consumers buy the same product from different small /large businesses. The product should be stripped of its differentiating characteristics viz:
i. standardisation removing variations
ii. usable when purchased without required alterations
iii. costs the same without regulations/pressures
iv. purchased as a transaction.

\subsection{Effects of Commoditisation on RTS}

Creates a liquidity market-with ease of buying and selling, with no brand identities and individual characteristics. Purchase becomes transactional and straight forward with increase in volume, creates variability in price and generates sales injecting cash into the market. Cash flows in the solar PV market can allow banks/lenders to write more loans to borrowers. Commoditisation can become beneficial for the PV industry and borrowers can achieve basis grade with minimum tolerable accepted standard. The key effect of commoditisation is that the pricing power of manufacturers/brand owners is weakened when RTS becomes more similar from a buyer's point of view and will tend be the cheapest.

\section{LITERATURE REVIEW}

Extensive literature survey was under taken to learn about commoditisation of RTS, but there has been no specific research done on this aspect of PV. The Energy Research Institute of India Report includes a chapter on how Commoditisation of RTS can augment growth of PV in India. The following literature reflects the research studies on the diverse subjects of solar PV which can contribute to our knowledge in enabling commoditisation of RTS in our country.

H. Sawaii, (1998) has analysed the spread process of RTS PV market formation based on governmental subsidy, market expansion and cost reduction showing their prime contribution in growth of PV. 
R. Haas et al., (1999) The importance of stake holders (PV system owners, manufacturers, utilities, local politicians) in the market penetration process and in the energy planning process of RTS has been discussed.

R. Stearns et al., (2009) have emphasised on the need for competency in PV technology and system design to be developed. Performing basic energy audits, systems sizing, appropriate PV technology selection and products development, solar workshops and training programmes, which makes interesting study.

West et al., (2010) elucidate the role of government in stimulating PV markets. Direct public involvement, start-up grants to put RTS within the reach of more consumers, to drive economies of scale and bring about low carbon building programmes. The importance of providing smart meters for furnishing up to date information on electricity consumption has also been addressed.

E. Miller et al., (2012) analyse how favourable policies and regulatory environment are determinants of a thriving solar market. They also address the fact that tax issues can be resolved through collaboration, consistency and predictable policies. Emphasis is placed on putting the standard policy in place to bring about education and widespread awareness and acceptance of the regulation.

V. Rai et al., (2015) discuss the different business models and show the expectations of people towards solar PV, the future technological trajectory and that the cost quality frontier of technology will have to evolve over time.

Eurostat, (2015) It is researched that PV systems should be prioritised in areas with higher solar irradiation and electricity grid, emphasising a need for increased electricity production from renewable energy systems including PV systems.

WWF Report on RE in India (2015) has pointed out the challenges faced by manufacturers and sellers of solar PV systems, like lack of awareness among consumers, cost driven decision making, lack of credit -collateral, poor credit worthiness, distorted capital markets, no ease of access to finance, losing faith in the industry -poor design, engineering implementation, installation, leading to improper and unsatisfactory results. Lack of government incentives/support mechanisms, lack of trained manpower and successful business models. Clueless of how to avail subsidies-which are tedious and time consuming to claim, and delayed disbursements of subsidies losing motivation. The necessity of training and skill building institutes for technical and marketing personnel is stressed upon. Manufacturers are few and scattered to provide proper after sales service.

Tayal \& Rauland, (2016) have driven home the fact that market participants must work with policy makers to drive flexibility in regulatory frameworks and progress the evolution towards innovative and sustainable electricity networks of the future.

E. Kabir et al., (2018) have examined the implications of technical barriers such as low solar cell efficiencies, low performing balance of costs, economic hindrances, high upfront costs and lack of financing mechanism.

\section{OBJECTIVES OF THE RESEARCH}

The objective of this research paper is to analyse the elements of commoditisation, the drivers of commoditisation and the barriers that hinder commoditisation of RTS in India. These can be further broken into sub -hypotheses as:

- the role of market dynamics in RTS commoditisation.

- the smart policies that can promote RTS commoditisation.

- the role of different stake holders in commoditisation of RTS. 
- the Institutional, Technological and Financial barriers and Other barriers that hinder commoditisation.

\section{RESEARCH METHODOLOGY}

Secondary data has been collected from Research articles, renewable energy journals like Akshay Urja, Renewable Watch, EQ International Modern Power Systems, Soft Disc India, Renewable Energy Booster, Energy Summit reports, websites of MNRE, TERI, NISE, SECI and other articles on solar energy from the internet.

The researcher is of the opinion that if India wants to progress in the uptake of solar PV, it needs to make RTS a commodity. Hence the researcher has attempted to study and analyse secondary data to learn about the elements of commoditisation, investigate the drivers of commoditisation and the challenges facing commoditisation. Inferences are drawn by delineating the characteristics of commoditisation and pointing out the barriers that confront speedy and effective commoditisation of RTS in India.

\section{ANALYSIS AND INTERPRETATION}

\subsection{Elements of Commoditisation of RTS}

Table 1 Source :TERI- Elements of Commoditisation of RTS.

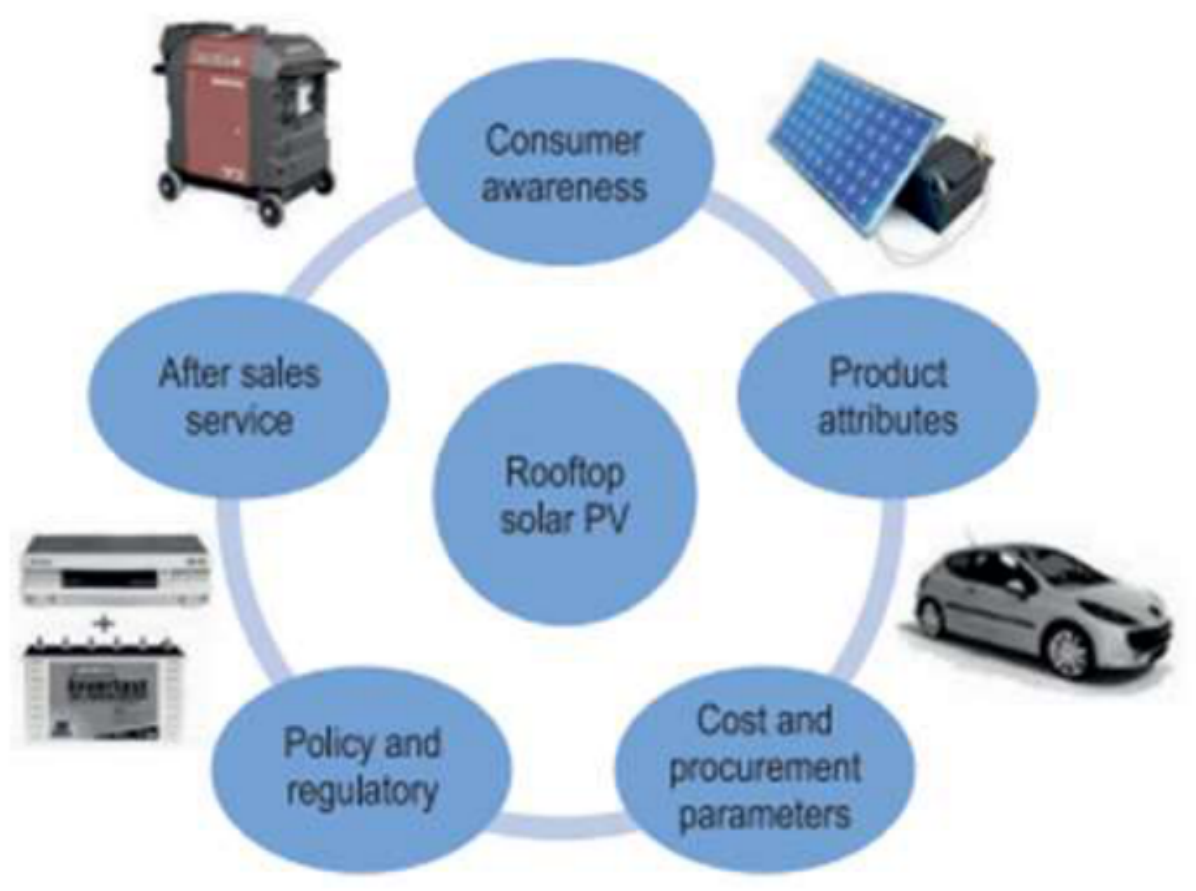

i. Consumer awareness-Lack of consumer awareness limits the utilisation of this important and freely available energy source. Advertisements over the media, newspapers, magazines, hoardings, radio, TV and Internet Workshops, Seminars and Awareness programmes can help.

ii. Desirable Product attributes like module efficiency, PV panels, stable, powerful, with salt mist and ammonia corrosion resistant, PID resistant with proven generation track record, manufactured with ISO certifications and 25 years output warranty and in house testing to ensure reliability can be aimed during imports and undertaking manufacturing of solar panels.

iii. Procurement/Cost based on ownership of RTS-PV system-solar lease contract of 1525 years, maintenance costs and replacement of spares and payment schedules are predetermined Power purchase agreement/per kWh-payment less than retail electricity rate and 
the rate proposed by the company offering PPAs $3^{\text {rd }}$ party PPAs -standard agreements will have to be uniformly adopted pan India wise.

iv. Policy/Regulatory. Existence of regulations for metering arrangement and connectivity standard regulations for energy accounting will have to be updated and implemented.

v. Ability to power all end use loads, to supply electricity $24 X 7$, to provide back-up power during outage, and to reduce grid electricity consumption taken into consideration.

vi. Ease of getting finance-financing innovations can be based on ownership of RSRTPVThird party ownership, homeowner ownership and Solar companies-full service solar developers providing installation and financing. Financial installers, financial lenders green banks, solar companies, credit unions, public private partnerships can come into foray.

vii. Options for buying through EMI Scheme, availability of third-party insurance, availability of Government incentives and ease of getting Government incentives. Competitiveness of unit cost of solar electricity with grid electricity will have to be aimed at.

viii. Ease of installation (network of suppliers and service providers), and after Sales Service, availability of annual maintenance contract from system suppliers has to be brought about.

\subsection{DRIVERS OF COMMODITISATION}

\subsubsection{Market and Industry Dynamics}

The solar market is still in its nascent stage in India and has not matured. India can learn the lessons from the successes and failures of policies adopted by the first mover markets like those of USA, Germany and Japan. With good market, technology costs would eventually fall and financing would become easier. There is lack of cost competitiveness of domestic solar cells and modules as compared to Chinese counterparts. The market for Indian modules is restricted to Roof Top segment which has a domestic content requirement. Low tariffs faced by manufacturers has led to reverse auction process driving module prices downwards and lowquality modules flooding the market. Market participants must work with policy makers to drive flexibility in the regulatory frameworks and progress the evolution towards innovative and sustainable solar market.

\subsubsection{Smart Policies}

i.Net metering policies give system owners credit on their utility bills for generating more electricity than their use, generally at full retail electricity rates.

ii. Transmission and distribution losses is less than $1 \%$ as power is consumed at the point of generation. Transmission capacities are insufficient and owing to inter State transmission congestion, Power Grid Corporation of India Limited, needs to build separate transmission lines to evacuate green energy within the States, the local governments have to invest in capacities. There is no resilience in grid and there is growing cost of grid power in India.

iii. Preferential feed in tariffs: Homeowners and businesses are paid under standardised contracts offering fixed prices for solar generation over an established often long-term period. Feed in tariffs can be classified by a number of factors including price paid, length of time payments are guaranteed, maximum size of installation allowed and type of customers allowed to participate.

iv. Value of solar tariffs: quantify the benefit of providing electricity and also the value of providing instantaneous power to the grid, avoiding use of fossil fuels.

v. Solar carve outs: Small scale solar can be targeted by States within their broader efforts to increase investments in renewable energy or distributed generation as part of the broader 
renewable electricity standards. These solar carve outs can offer solar system owners, potential additional revenue.

vi. Tax incentives/subsidies and tax holidays: RTS as clean energy alternative has to be encouraged with low interest loans In addition to $30 \%$ tax credit, states should have tax incentives for home owners, and property tax exemptions.

Table 2 Interventions and actions required by responsible Indian organisations

\begin{tabular}{|c|c|c|}
\hline $\begin{array}{c}\text { Areas of } \\
\text { intervention }\end{array}$ & Actions required & Roles and responsibilitios \\
\hline $\begin{array}{l}\text { Creating } \\
\text { awareness }\end{array}$ & $\begin{array}{l}\text { - "Bolar Shop" at commercial } \\
\text { establishments } \\
\text { - Bpread information through } \\
\text { advertisements } \\
\text { - A dedicated website for rooftop } \\
\text { BPV } \\
\text { - Design competitions }\end{array}$ & $\begin{array}{l}\text { - Private developers to open solar } \\
\text { shops } \\
\text { - MNRE and BNAs to support } \\
\text { private entities }\end{array}$ \\
\hline $\begin{array}{l}\text { Promoting } \\
\text { standard PV } \\
\text { systems }\end{array}$ & $\begin{array}{l}\cdot 1-10 k W_{p} \text { for residential } \\
\text { - } 10-100 k W_{p} \text { for commercial } \\
\text { - }>100 k W_{p} \text { for industrial }\end{array}$ & $\begin{array}{l}\text { - Bolar developers to manufacture } \\
\text { and promote SPV systems } \\
\text { - MNRE and BNAs help to achieve } \\
\text { economy of scale }\end{array}$ \\
\hline $\begin{array}{l}\text { Tochnical } \\
\text { standards for LT } \\
\text { connectivity }\end{array}$ & $\begin{array}{l}\text { - Noed to follow, CEA guidelines, } \\
\text { Net-metering guidelines, G83-1/1 } \\
\text { (EN } 50438 \text { ), IEC } 61727 \text { and IEC } \\
62116\end{array}$ & $\begin{array}{l}\text { - CEA to strengthen technical } \\
\text { standards } \\
\text { - Distribution company to specify } \\
\text { upper limit for capacity addition }\end{array}$ \\
\hline $\begin{array}{l}\text { Belf- } \\
\text { consumption } \\
\text { during power } \\
\text { outage }\end{array}$ & $\begin{array}{l}\text { - Grid interactive system with } \\
\text { storage should be promoted. } \\
\text { - Promote indigenous } \\
\text { manufacturing to reduce overall } \\
\text { system cost }\end{array}$ & $\begin{array}{l}\text { - Developers to manufacture SPV } \\
\text { system } \\
\text { - MNRE and BNAs to support } \\
\text { developers and consumers }\end{array}$ \\
\hline $\begin{array}{l}\text { Quality } \\
\text { assurance for } \\
\text { rooftop SPV }\end{array}$ & $\begin{array}{l}\text { - Introducing star rated programme } \\
\text { for rooftop BPV system }\end{array}$ & $\begin{array}{l}\text { - MNRE and BIS/CEA to take } \\
\text { initiatives }\end{array}$ \\
\hline $\begin{array}{l}\text { Creating } \\
\text { infrastructure } \\
\text { for after sales } \\
\text { service }\end{array}$ & $\begin{array}{l}\text { - National and rogional level skill } \\
\text { development and training centres } \\
\text { - Bervice centres by solar } \\
\text { companies } \\
\text { - Certification of technicians }\end{array}$ & $\begin{array}{l}\text { - MNRE, SNAs, technical training } \\
\text { institutes, and solar companies to } \\
\text { take initiatives }\end{array}$ \\
\hline
\end{tabular}




\begin{tabular}{|c|c|c|}
\hline $\begin{array}{l}\text { Areas of } \\
\text { intervention }\end{array}$ & Actions required & Roles and responsibilities \\
\hline $\begin{array}{l}\text { Btrengthen } \\
\text { supply chain for } \\
\text { rooftop SPV }\end{array}$ & $\begin{array}{l}\text { - Arailability of standard PV } \\
\text { system packages at electrical } \\
\text { shops/company outlets }\end{array}$ & $\begin{array}{l}\text { - Bolar companies and retail } \\
\text { Outlets to take initiatives }\end{array}$ \\
\hline Cost & $\begin{array}{l}\text { - Different capital subsidy for } \\
\text { different types of consumers } \\
\text { - More than one project can be } \\
\text { bundled and procured together for } \\
\text { cost reduction }\end{array}$ & $\begin{array}{l}\text { - MNRE and BNAs design the } \\
\text { subsidy mechunism } \\
\text { - Consumers to bundle projects }\end{array}$ \\
\hline $\begin{array}{l}\text { Financing } \\
\text { schemes }\end{array}$ & $\begin{array}{l}\text { - Easy financing and EMI payment } \\
\text { options } \\
\text { - MNRE subsidy for establishing } \\
\text { distributorship/retailer ship }\end{array}$ & $\begin{array}{l}\text { - MNRE and BNAs to take initiative } \\
\text { - Rural, and other nationalized and } \\
\text { private banks to finance }\end{array}$ \\
\hline $\begin{array}{l}\text { Generating } \\
\text { funds }\end{array}$ & $\begin{array}{l}\text { - Government or municipality can } \\
\text { raise funds through green bonds }\end{array}$ & $\begin{array}{l}\text { - MNRE, SNAs, and municipality to } \\
\text { take initiatives }\end{array}$ \\
\hline $\begin{array}{l}\text { Bimple approval } \\
\text { procedures }\end{array}$ & $\begin{array}{l}\text { - Single window clearance } \\
\text { - Online processing of application } \\
\text { - Removal of unnecessary } \\
\text { clearances }\end{array}$ & - MNRE and BNAs \\
\hline RPO and REC & $\begin{array}{l}\text { - Electricity from rooftop SPV } \\
\text { should be used by DIBCOMB to } \\
\text { claim REC }\end{array}$ & - DISCOMS, CERC, and SERCs \\
\hline $\begin{array}{l}\text { Monitoring, } \\
\text { control, and } \\
\text { verification }\end{array}$ & $\begin{array}{l}\text { - Energy accounting at regular } \\
\text { intervals should be done } \\
\text { - SPV system as a product should } \\
\text { be certified for enhancing } \\
\text { confidence on the product by the } \\
\text { consumers as well as bunks } \\
\text { - BNAs should check product } \\
\text { quality and its implementation. }\end{array}$ & $\begin{array}{l}\text { - DISCOMS, SNAs, MNRE, and } \\
\text { certifying agencies }\end{array}$ \\
\hline $\begin{array}{l}\text { Lack of roof } \\
\text { spuce }\end{array}$ & $\begin{array}{l}\text { - Poople living in high rise } \\
\text { buildings ( }>3 \text { storeys) should } \\
\text { invest in green bonds } \\
\text { - Rooftop SPV should be } \\
\text { compulsory for new government } \\
\text { buildings, educutional institutes, } \\
\text { and hospitals }\end{array}$ & $\begin{array}{l}\text { - Consumers, development } \\
\text { authorities, real estate } \\
\text { developers, SNAs, and MNRE } \\
\text { should follow coordinated } \\
\text { approach }\end{array}$ \\
\hline $\begin{array}{l}\text { Replication of } \\
\text { web GIS tool for } \\
\text { other cities }\end{array}$ & $\begin{array}{l}\text { - Phase wise targeting of several } \\
\text { more cities }\end{array}$ & - BNAs, BECI, and NRBC \\
\hline
\end{tabular}

\section{Source :TERI}




\subsubsection{Stake Holders}

Manufacturers, DISCOMS, Developers, Installers, Equipment Procurement Commissioners, Financiers, State Electricity Boards, Central Government all have a key role to play. Ministry of new and renewable energy(MNRE),National Institute of Solar Energy(NISE),Solar Energy Corporation of India,(SECI) in formulation of solar energy policies for proper implementation and subsidy ,State governments to fix Solar energy development targets, monitor State Nodal Agencies for solar development and. frame annual Solar policy for the State and implement the same, sign PPAs with power suppliers, pay for power purchase in time, mandatorily adopt the Energy Conservation Building Code. DISCOMs, Investors and Consumers need to coordinate across all the stake holders to help the RTS achieve its true potential. The added advantages of RTS is that there is no pooling of land required, no separate transmission facilities required. Consumers can become PROSUMERS -active participants in the RTS. It is estimated that $70 \%$ of building stock will be required in 2030 which is yet to be constructed. Support provided by MNRE through skill development programme, financial assistance, incentives, concessional finance for developers, focussed awareness programme should help provide an additional impetus. Government should not leave the public acceptance of RTS to market forces but should internalise the risks and costs for long term benefits. Only if all the stake holders collate can there be the required progress in commoditisation of RSRTPVs in India.

\subsection{Challenges Facing Commoditisation}

5.3.1Solar policies: Several provisions under the Electricity Act ,2003, mandate the Electricity Regulatory Commissions and the Government to take necessary steps for promotion of Renewable Energy. Sections 108 and 109 of the Electricity Act 2003 mandate the Government to give directions to the State Commission in the matter of policy involving public interest. Accordingly, State Governments formulate their own Solar policies and there is absolutely no nation-wide parity with policy complexity driven by Centre and State-unclear cross subsidy surcharge; uneasy interstate exports of electricity distributed solar.

5.3.2 Net metering implementation: Net metering is the system by which the customers who generate their own electricity from solar power can feed their unused electricity back into the grid and be compensated for that. The heavily subsidised solar tariff rates discourage customers from net metering.

5.3.3 Grid instability: India's outdated grid interface needs to be modernised into a smart grid capable of handling the greater share of generation of new low-cost solar energy. To resolve grid integration issues, Power Grid Corporation of India Limited, has started setting up Regional Energy Management Centres (REMCs) and a number of State Regulatory Commissions. Further the implementation of Smart Grid Pilots and the Smart Cities Programme are some of the measures taken by the authorities to facilitate this transition. Grid connectivity issues like power quality, voltage frequency fluctuations, islanding, harmonics. transmission and distribution system affecting power electronic converters.

5.3.4 Storage and Energy banking: When a generator is wheeling electricity in some markets, it can virtually bank the electricity for consumption by an end consumer at a later time. The bank is not a physical energy storage facility, but rather, energy is virtually banked through accounting methods. For example, if a solar generator produces during the day, but wants to sell to a consumer that needs electricity at night, banking service allows the generator to put all of its generation on the grid during the day and then use banked grid supplied energy to serve the customer's needs at night. The biggest challenge is the high cost of storage in India. Although storage prices have come down by 45\%, between 2010 and 2017, it is still costly. With efficient storage, the problem of power wastage can be resolved. 
5.3.5 Weak Transmission Infra structure: There is a lack of integrated generation and transmission planning to support solar power. Timely augmentation of transmission capacity will be the key to avoiding the accumulation of generation capacity.

5.3.6 Financing: Reserve Bank of India has included RSRTPV under Priority sector lending for which bank loans are available. With subsidised financing now available from large banks, the pace of growth of this segment can speed up. The interest rate for providing finance to solar manufacturers by domestic lenders stands at $13-17 \%$, depending on the credit worthiness of the manufacturer. Banks can extend loans up to a limit of Rs $15 \mathrm{crores}$, to corporate borrowers and up to Rs10 lakhs to individual borrowers for RSRTPV. In contrast, foreign institutions provide loans to manufacturers at interest rates as low as $5 \%$, thus bringing down the cost of production and sale price. Different mechanisms of financing need to be exploredleasing a roof, demand aggregation, credit risk guarantee mechanism etc.

5.3.7: Green Financing: To drive a harmony between the economy and the environment, green banking initiatives are being taken by the leading public and private sector banks in India. MNRE and IREDA are developing green windows for institutional design, structure and financial institutions as sources of capitalisation, technical assistance and capacity building with strong knowledge partners like NRDC and CEEW. Green banks have been visualised as implementation strategy of RE for Paris agreement. Knowledge exchange among countries with green banks is happening. India can therefore use these as catalytic financing tools for attracting low cost finance to grow green infra structure projects like RTS.

\section{RESULTS AND DISCUSSION}

\subsection{Characteristics of Commoditisation}

6.1.2 Standardisation: The Solar PV Roof top for residential sites should be available in a range of standardised packages. The production of components like batteries and inverters is undertaken in India while solar panels are imported from China. 'Make in India' concept of developing different standard size packages of Residential Solar Roof Tops can help. Presently the manufacturers procure components from a variety of suppliers, resulting in varying levels of quality. Further the models built using US/European data need extensive validation for India. CEA-the Central Energy Agency needs to strengthen technical standards.

6.1.3 Generating Capacity: Reduce costs, improve efficiency with a view to increase generating capacity. Market transformation has to come with focus on capacity building with optimised technologies leading to increased number of RTS installations.

6.1.4 Quality: State Nodal Agencies can be made responsible to check RTS product quality. Standard system configuration, certification of technicians for installation, maintaining enhanced quality of installation.

6.1.5 Strengthening supply chain: A dedicated website for RTS needs to be set up and private developers can open solar shops for 1 to $10 \mathrm{kWp}$ for Residential sector through solar companies and retail outlets. Bulk purchasing of PV systems can bring about reduction in upfront capital costs. Soft loans as support from the government can help stabilize the market.

6.1.6 Accessibility: The product should be backed by a wide network of suppliers and service providers. Solar technology solutions should be easily available and accessible as a complete product or as a package in the market. Consumers need to be fully aware of the service levels and actual economic benefits. Well established solar service networks should exist just like those for other high-end commodities.

6.1.7 Affordability: The product should be available through easy financing and availability of financial models. Banks, home finance companies can undertake client 
assessment and make loan security disbursal and recovery. Accurate calculations for Internal Rate of Return, Equity Pay back, Annual savings and Levelized cost of electricity should be made. Easy computations with default values for tax rates, discount factors, power generation based on solar plant capacity and provision for net metering should be taken into account and different interest rates worked out for CAPEX (Capital expenditure) /BOOT (Build, Own, Operate)/ Pay as you use- Models to enable consumers to make wise choices. Easy finance schemes for procurement of Roof Top Solar PV Systems through banks should become part of the building infrastructure during acquisition of homes.

6.1.8 Peoples participation: People can invest in green bonds, while Government and municipalities can raise funds through green bonds.

\subsection{Barriers to Commoditisation}

There are three main types of barriers viz: Institutional, Technological and Financial barriers for commoditisation of RSRTPV.

6.2.1 Institutional barriers like leveraging and integrating new technologies into the existing grid structures and business models like grid plus distributed solar model. Psychology of people, their reluctance to embrace the new, consumer inertia, and information blocks has to be tackled.

6.2.2 Technological barriers like constraints of existing technology, network capacity access, limited standardisation of roof top solar PV systems, inadequate supply chain, inadequate experience of grid connectivity at low voltage, limitations of solar systems to function during power outage, higher cost of dual function inverter, (which allows consumption of solar electricity during power outage) etc.

6.2.3 Financial barriers like high upfront costs, limited financing schemes by banks, high cost of debt, high interest rates, return on equity, development costs, inflation, carbon financing -all these can be overcome by evolving National policy guidelines regarding uniform application of these financial imperatives.

6.2.4 Other barriers like lack of awareness among consumers, cost reduction for small capacity SPV systems, few companies dealing with small capacity PV systems, obtaining better tools to reduce variability and uncertainty of power. Lack of clarity on government support on policy and regulatory front.

\section{IMPLICATIONS OF THE STUDY}

- The study can augur growth of commoditisation of RTS as a commercial product in the PV market.

- The study can highlight the importance of economies of scale and capacity building which can happen only through the process of standardisation of the product and eventually commoditisation.

- Knowledge of commoditisation, its potential impact on manufacturing and installation of RTS will call for integration of competent professionals from diverse fields of technology, human resource, finance, marketing and information technology to achieve the desired results.

- The study beckons for standardisation of RTS as a product which is so vital for aggressive marketing

- The study calls for inclusion of stake holder responsibility aspect to be taken into consideration while formulating regulatory policies. 
- It is hoped that better financing options will be implemented for uptake by more consumers.

\section{CONCLUSION}

Solar PV is a core technology, it is not sold in the market as a commodity, today it is seen as a project mainly accessed by solar developers, solar agencies and solar installers capitalising on the affordability of the affluent cross sections of the Indian society. For the technology to reach the grass root levels and the remote inaccessible areas of rural India where electricity has not reached -PV off grid with battery storage can be a solution. Commoditisation calls for different ready to plug in models - on grid or off grid types catering to Residential, Commercial /Industrial segments. It is felt that R\&D efforts and integration of all Stake holders in theory and practice is called for to contemplate in arriving at compatible and feasible technological solutions not sacrificing quality and cost.

As of now, India's energy deficit is eliminated with India turning a net exporter of electricity, MNRE states that India globally ranks $5^{\text {th }}$ in terms of overall renewable energy capacity. With continuing decreasing cost of RTS and increasing cost of fossil fuels, grid parity can occur within three to four years in several States of India where high solar resource and prevailing high tariffs of electricity are available. The construction of residential buildings is rapidly taking place with the increasing population in urban areas and RTS can replace grid during sunshine period. The load of domestic consumers generally ranges from $5 \mathrm{~kW}$ to $20 \mathrm{~kW}$, but domestic consumers are less in the category of $20 \mathrm{~kW}$ so the average load of $10 \mathrm{~kW}$ will be ideal for Residential sector in India.

There is economic growth leading to urbanisation and increasing demand for electricity owing to increase in urban Indian population. As per UN projections (UN 2006) Indian urban population would be $41 \%$ by 2030 and $50 \%$ by 2050 , if the same growth trend continues. With the rising population, rising consumption of electricity, technological improvement together with commoditisation of the RTS product has to take place to make a positive impact on the present-day society and the environment. To cap it all, commoditisation of RTS can be an ideal solution to increase adoption of RTS on every roof harnessing solar energy and making the act of buying a ready built plug in PV systems off the shelf in Indian PV markets- a reality though difficult but not an impossibility.

\section{REFERENCES}

[1] E. Kabir, P. Kumar, S. Kumar, A. A. Adelodun, and K. H. Kim, "Solar energy: Potential and future prospects," Renewable and Sustainable Energy Reviews, vol.82. pp. 894-900, 2018.

[2] R. Stearns, "The Case for Photovoltaics," Resid. Syst., vol. 10, no. 7, p. 20, 2009.

[3] R. Haas, M. Ornetzeder, K. Hametner, A. Wroblewski, and M. Hübner, "Socio-economic aspects of the austrian 200 kwp-photovoltaic-rooftop programme," Sol. Energy, vol. 66, no. 3, pp. 183-191, 1999.

[4] Ashutosh Kumar, Dr. Prabhat Kumar, Dr. N. Manoharan and Thivya Gopalan, Transformation from A Conventional "Commodity" To A "Brand" of Cement And Its Impact. International Journal of Advanced Research in Engineering and Technology, 6(8), 2015, pp. 94-106

[5] H. Sawai, "For real spread of photovoltaic residential system," Shapu Giho/Sharp Tech. J., no. 70 , pp. 44-48, 1998. 
[6] Hameed Majeed Saber and Deepak Lal, "Assessment of Solar Energy Distribution for Installing Solar Panels using Remote Sensing \& GIS Techniques", International Journal of Advanced Research in Engineering and Technology (IJARET), Volume 5, Issue 10, October (2014), pp. 157-164.

[7] The Impact of Net Metering on the Residential Roof Top PV Market, Adam M. Payne, Richard D. Duke, Robert H. Williams, Princeton University.NJ08540

[8] Barriers and Opportunities for Residential Solar PV and storage markets-A western Australian case study-by Dev Tayal and Vanessa Rauland.

[9] Saad S. Alrwashdeh, Comparison among Solar Panel Arrays Production with a Different Operating Temperatures in Amman-Jordan, International Journal of Mechanical Engineering and Technology 9(6), 2018, pp. 420-429.

[10] V. Rai and A. L. Beck, "Public perceptions and information gaps in solar energy in Texas," Environ. Res. Lett., vol. 10, no. 7, 2015.

[11] E. Miller, E. Nobler, C. Wolf, and E. Doris, "Market Barriers to Solar in Michigan," NREL Tech. Rep., no. August, pp. 1-28, 2012.

[12] Filling the skill gap in India's clean energy market Solar energy focus NRDC and CEEW Issue Brief

[13] Roof top PV experience in India.www.teri.in.org/event docs/files/rooftop solar pv-exp-mar pdf

[14] www.nrel.gov>docs by CPIXO1

[15] http://www.bloomberg.com/news/articles/2017/12-18

[16] Roof top solar-does it make sense for Residential solarwww.solarmango.com/in/residential/solarpv

[17] www.reuters.com

[18] www.greenubuntu.com

[19] http://www.architecture anddesigns.com/53amazing terraces and rooftops 